\title{
Kasus Perundungan Anak di Jawa Barat: Temuan Awal Children's Worlds Survey di Indonesia
}

\author{
Ihsana Sabriani Borualogo, Erlang Gumilang \\ Fakultas Psikologi, Universitas Islam Bandung, Indonesia \\ e-mail: ihsana.sabriani@unisba.ac.id
}

\begin{abstract}
This study aimed to describe the rate of bullying cases on children age 8, 10, and 12 year-olds in 27 cities in West Java. There were 22.616 children age 8, 10, and 12 year-olds who participated in this survey. This survey used stratified cluster random sampling to get a representative sample. Bullying actions were measured by reported frequency of experiencing being bullied physically and verbally by siblings and being bullied physically, verbally, and psychologically by other children at school last month. The highest rate was children reported being bullied physically by siblings and being bullied verbally by other children at school. Results show differences on age and gender on types of bullying. Bullying is a serious problem that needs to be taken into account to stop bullying cases in West Java.
\end{abstract}

Keywords: bullying, children, West Java, Children's Worlds Survey

\begin{abstract}
Abstrak
Penelitian ini bertujuan untuk mendeskripsikan data kasus perundungan pada anak usia 8, 10, dan 12 tahun di $27 \mathrm{Kota} /$ Kabupaten di Jawa Barat. Terdapat 22.616 anak usia 8, 10, dan 12 tahun yang berpartisipasi dalam penelitian ini. Untuk mendapatkan sampel yang representatif, digunakan teknik stratified cluster random sampling. Perilaku perundungan diukur melalui frekuensi mengalami perundungan fisik dan verbal oleh saudara kandung serta frekuensi mengalami perundungan fisik, verbal, dan psikologis oleh anak lain di sekolah dalam satu bulan terakhir. Frekuensi tertinggi adalah anak melaporkan menjadi korban perundungan fisik yang dilakukan oleh saudara kandung dan menjadi korban perundungan verbal yang dilakukan oleh anak lain di sekolah. Hasil menunjukkan perbedaan usia dan jenis kelamin pada tipe perundungan. Perundungan adalah persoalan serius yang harus menjadi perhatian dalam upaya menghentikan terjadinya kasus perundungan di Jawa Barat.
\end{abstract}

Kata Kunci: perundungan, anak, Jawa Barat, Children's Worlds Survey

\section{Pendahuluan}

Bullying atau dalam Bahasa Indonesia dikenal sebagai perundungan, merupakan persoalan serius pada anak-anak di hampir sebagian besar negara di dunia ini. Perundungan didefinisikan sebagai tindakan agresif yang dimaksudkan untuk menyakiti korban, baik secara fisik (misalkan, dengan memukul atau menendang), secara psikologis (misalkan, melalui ancaman ataupun memanggil dengan julukan yang buruk), maupun secara sosial (misalkan dengan mengucilkan atau mengabaikan korban), yang dilakukan secara sengaja, berulang, dan menunjukkan adanya perbedaan kekuatan antara pelaku dan korban (Olweus, 1997; Espelage \& Swearer, 2003; Wang, Ianotti, \& Nansel, 2009).

Laporan yang dikeluarkan oleh UNESCO pada bulan Oktober 2018 berdasarkan Global school-based Student Health Survey (GSHS) yang melibatkan 144 negara mengungkapkan bahwa $16.1 \%$ anak-anak pernah menjadi korban perundungan secara fisik. Student Reports of Bullying yang dikeluarkan oleh Departemen Pendidikan Amerika Serikat pada tahun 2016 menunjukkan bahwa 20.8\% siswa di 
Amerika Serikat pernah menjadi korban perundungan (U.S. Department of Education, 2016). Sebuah penelitian di Hong Kong mengungkapkan bahwa 70\% dari 1.800 siswa pernah menjadi korban perundungan di sekolah (Syed, 2018). Penelitian lain menunjukkan bahwa sebanyak 79\% siswa di Vietnam dan Nepal pernah menjadi korban perundungan, dan sebanyak $73 \%$ siswa di Cambodia dan $43 \%$ siswa di Pakistan juga menjadi korban perundungan (Sindo Weekly, 2017). Datadata tersebut menunjukkan bahwa fenomena perundungan merupakan persoalan serius bagi anak-anak di dunia.

Fenomena serupa juga terjadi di Indonesia. Perundungan juga merupakan persoalan serius dan mengancam bagi anak Indonesia. Melalui berita di media massa, kita seringkali dikejutkan oleh kasus-kasus perundungan yang sangat memprihatinkan dan semakin sering terjadi di Indonesia. Terdapat kasus-kasus perundungan yang secara sengaja dipublikasikan oleh pelaku melalui media sosial. Tidak jarang kasuskasus perundungan berujung pada kematian akibat tindak kekerasan yang dialami korban, maupun kasus-kasus perundungan yang mengakibatkan korban melakukan upaya bunuh diri karena merasa sangat tertekan.

Sebuah studi menunjukkan bahwa $84 \%$ anak-anak Indonesia pernah menjadi korban perundungan (Sindo Weekly, 2017). Data ini sangat mengejutkan karena menempatkan Indonesia sebagai negara dengan tingkat perundungan tertinggi di antara negaranegara Asia lainnya.

Kementerian Perencanaan Pembangunan Nasional dan Unicef (2017) memaparkan hasil survei yang dilakukan pada tahun 2015 oleh The Global School-Based Health Survey yang menunjukkan bahwa $32 \%$ siswa-siswi usia 13 sampai 17 tahun di Indonesia telah mengalami kekerasan fisik dan 20\% siswa-siswi menjadi korban perundungan di sekolah.

Komisi Perlindungan Anak Indonesia (KPAI) pada periode 2011-2017 menerima 26.000 kasus perlindungan anak, di mana
34\% dari kasus tersebut adalah kasus perundungan. Pada tahun 2018, KPAI menerima 161 laporan kasus perlindungan anak, di mana 36 kasus $(22.4 \%)$ adalah kasus korban perundungan dan 41 kasus (25.5\%) adalah kasus pelaku perundungan (Novianto, 2018).

Informasi mengenai jumlah korban perundungan di Indonesia masih bersifat terbatas, karena pada umumnya informasi diperoleh berdasarkan laporan dari korban, sementara tidak semua korban perundungan bersedia melaporkan kejadian yang mereka alami. Keterbatasan informasi mengenai jumlah korban perundungan juga terjadi karena masih sangat terbatasnya studi yang mengkaji jumlah kasus perundungan di Indonesia, sehingga pada umumnya data diperoleh berdasarkan laporan di media massa atas kasus perundungan.

Mengingat perundungan merupakan kasus serius yang dialami anak-anak, serta masih sangat terbatasnya informasi mengenai kasus perundungan pada anak usia sekolah dasar, maka penelitian ini menggali informasi mengenai frekuensi perundungan pada anak untuk mendapatkan jumlah yang lebih pasti mengenai kejadian perundungan.

Penelitian ini merupakan bagian dari kegiatan survei internasional Children's Worlds yang pengambilan datanya dilakukan di Jawa Barat, Indonesia. Children's Worlds (www.isciweb.org) adalah organisasi dunia yang melakukan survei internasional kesejahteraan anak di lebih dari 40 negara di dunia. Saat ini, Children's Worlds telah menyelesaikan gelombang tiga survei internasionalnya, di mana Indonesia berperan serta aktif dalam penelitian ini. Di Indonesia, survei ini diberi nama sebagai Survei Kebahagiaan Anak yang pelaksanaan pengambilan datanya dilakukan dalam kerangka kerjasama antara UNISBAUNICEF Indonesia yang didukung secara penuh oleh Pemerintah Republik Indonesia (BAPPENAS dan BPS).

Children's Worlds menjelaskan mengenai adanya dua tipe perundungan, yaitu perundungan di sekolah dan perundungan yang dilakukan oleh saudara kandung di 
rumah, baik secara fisik, psikologis, dan verbal. Data mengenai frekuensi perundungan diperoleh berdasarkan laporan langsung dari anak yang menjadi korban perundungan di Jawa Barat dengan menjawab kuesioner yang diberikan kepada anak usia 8, 10, dan 12 tahun.

Survei internasional ini merupakan pionir dalam melaksanakan survei pada anak usia sekolah dasar, di mana kajian literatur menunjukkan adanya kesenjangan informasi dan pengetahuan mengenai kasus-kasus perundungan pada anak usia sekolah dasar. Survei internasional yang dilakukan oleh Children's Worlds di Indonesia ini menjadi penting untuk mengisi kesenjangan informasi tersebut dan menumbuhkan kesadaran pada orang tua dan guru mengenai kasus perundungan yang dilakukan oleh saudara kandung di rumah dan anak lain di sekolah berdasarkan laporan yang disampaikan oleh anak-anak pada kasus perundungan fisik, psikologis, dan verbal.

Didasari keprihatinan atas tingginya kasus perundungan di Indonesia, bahkan David Beckham, seorang legenda sepak bola dunia, berkunjung ke Indonesia pada Maret 2018 untuk menunjukkan keseriusannya dalam memerangi perundungan di Indonesia melalui yayasan the 7 Fund yang didirikannya (Pennington, 2018).

Berbagai penelitian menunjukkan bahwa perundungan dapat berkontribusi pada masalah kesehatan mental anak (Arseneault, Bowes, \& Shakoor, 2009), meningkatkan ide untuk melakukan bunuh diri (Kim, Koh, \& Leventhal, 2005; Lenci \& Matuga, 2010; Wang, Iannotti, \& Nansel, 2009), memengaruhi harga diri anak (Dombrowski \& Gischlar, 2006; Musu-Gillette, Zhang, Wang, Zhang, \& Oudekerk, 2017), meningkatkan masalah perilaku dan menurunkan perilaku prososial (Wolke, Woods, Bloomfield, \& Karstadt, 2000), meningkatkan masalah serius dalam perkembangan anak (Dombrowski \& Gischlar, 2006), meningkatkan risiko masalah-masalah psikosomatik, seperti sakit kepala dan sakit perut (Gini \& Pozzoli,
2013), menghambat penyesuaian diri (Perren, Ettekal, \& Ladd, 2013), menurunkan kepuasan hidup (Varela, Zimmerman, Ryan, Stoddard, Heinze, \& Alfaro, 2017), meningkatkan depresi (Chen \& Wei, 2011), memberikan pengaruh negatif pada subjective well-being anak (Savahl, Montserrat, Casas, Adam, Tiliouine, Benninger, \& Jackson, 2018; Tiliouine, 2015), serta rendahnya kepuasan akan hidup pada anak yang menjadi korban perundungan di sekolah (Martin, Huebner, \& Valois, 2008).

Hasil-hasil penelitian tersebut sejalan dengan pernyataan Casas (2016) bahwa terdapat tiga prediktor yang sangat kuat dalam menentukan subjective well-being pada anak, yaitu (1) perundungan, (2) persepsi mengenai rasa aman, dan (3) penghargaan terhadap anak dan mendengarkan pendapat mereka.

Walaupun terdapat sejumlah data yang menjelaskan angka kejadian perundungan di Indonesia, namun data-data tersebut bukan diperoleh dari pengambilan data perundungan melalui anak secara langsung. Menanyakan secara langsung kepada anak mengenai kehidupan mereka, sangatlah penting karena anak adalah orang yang paling memahami mengenai kehidupannya (Casas, Gonzalez, Navarro, \& Aligue, 2013). Hal ini yang mendasari Children's Worlds untuk melakukan pengambilan data pada anak sebagai narasumber utama kehidupan mereka.

Melalui alat ukur perundungan yang dibuat oleh Children's Worlds dan telah diadaptasi ke dalam Bahasa Indonesia (Borualogo, Gumilang, Mubarak, Khasanah, Wardati, Diantina, Permataputri, \& Casas, 2018), diperoleh data frekuensi terjadinya perundungan pada siswa sekolah dasar yang dilaporkan secara langsung oleh anak.

Tujuan objektif dari artikel ini adalah memaparkan hasil temuan frekuensi terjadinya perundungan pada anak usia 8, 10, dan 12 tahun di 27 Kota/ Kabupaten di Jawa Barat yang diperoleh langsung dari laporan anak atas frekuensi terjadinya perundungan pada dirinya. Data ini merupakan temuan 
awal dari hasil survei internasional Children's Worlds di Indonesia. Melalui deskripsi data awal perundungan ini, diharapkan dapat dijadikan bahan rujukan bagi peneliti yang tertarik melakukan penelitian mengenai perundungan, terutama sebagai rujukan angka kejadian perundungan pada anak sekolah dasar di Jawa Barat. Dengan demikian, diharapkan frekuensi data perundungan ini dapat dijadikan sebagai dasar pijakan untuk memahami fenomena perundungan pada siswa sekolah dasar di 27 Kota/ Kabupaten di Jawa Barat.

\section{Metode Penelitian}

Metode yang digunakan dalam penelitian ini adalah survei, sehingga dapat menangkap fenomena perundungan secara lebih komprehensif pada anak-anak usia sekolah dasar yang diperoleh datanya secara langsung melalui anak.

Data penelitian ini berdasarkan hasil Survei Kebahagiaan Anak yang dilakukan di Jawa Barat pada Oktober 2017 yang merupakan kerjasama penelitian internasional antara Unisba, Unicef Indonesia, dan Children's Worlds (www.isciweb.org).

\section{Sampel}

Teknik sampling yang digunakan dalam penelitian ini adalah stratified cluster random sampling. Sekolah dasar merupakan unit sampling dalam penelitian ini. Tim peneliti memiliki daftar lengkap seluruh sekolah dasar dan madrasah ibtidaiyah di Provinsi Jawa Barat yang diperoleh dari Dinas Pendidikan dan Kebudayaan Provinsi Jawa Barat. Peneliti menyusun kerangka sampling dari seluruh daftar sekolah dasar dan madrasah ibtidaiyah tersebut.

Stratifikasi dilakukan berdasarkan ranking sekolah yang diperoleh dari nilai akreditasi sekolah. Klaster dilakukan pada tipe sekolah, yaitu sekolah negeri dan sekolah swasta, serta sekolah berbasis agama dan sekolah tidak berbasis agama.

Setelah selesai menyusun daftar lengkap sekolah berdasarkan stratifikasi dan klaster, barulah kemudian peneliti memilih sekolah secara random. Terdapat 10 sekolah yang terpilih dari tiap Kota/ Kabupaten di Jawa Barat, sehingga terdapat 270 sekolah yang terpilih. Namun, dalam pelaksanaan pengambilan data di lapangan, 1 sekolah terpilih tidak dapat dilaksanakan pengambilan data, 1 sekolah terpilih sudah tidak beroperasi, dan 2 sekolah telah bergabung menjadi satu, sehingga total terdapat 267 sekolah dasar yang menjadi unit sampling penelitian ini.

Partisipan penelitian ini adalah siswa SD (N=22.616) kelas 2, 4, dan 6. Siswa usia 8 tahun (rata-rata usia $=7.84$ ) berada di kelas 2 SD (32.90\%), siswa usia 10 tahun (rata-rata usia 9.66) berada di kelas 4 SD (32.20\%), dan siswa usia 12 tahun (rata-rata usia 11.53) berada di kelas 6 SD $(35.00 \%)$. Terdapat $49.50 \%$ anak laki-laki dan $49.70 \%$ anak perempuan, serta sebanyak $.8 \%$ tidak mengisi data jenis kelamin. Data terinci mengenai sampel penelitian ini disajikan dalam tabel 1 .

Tabel 1

Karakteristik Sampel

\begin{tabular}{lcccc}
\hline & $\begin{array}{c}\text { Usia 8 } \\
\text { tahun }\end{array}$ & $\begin{array}{c}\text { Usia 10 } \\
\text { tahun }\end{array}$ & $\begin{array}{c}\text { Usia 12 } \\
\text { tahun }\end{array}$ & Total \\
\hline Laki-laki & 3.710 & 3.629 & 3.852 & 11.251 \\
Perempuan & 3.657 & 3.592 & 4.002 & 11.191 \\
Missing & 65 & 55 & 54 & 174 \\
Total & 7.432 & 7.276 & 7.908 & 22.616 \\
\hline
\end{tabular}

\section{Persiapan Pengambilan Data}

Persiapan pengambilan data dilakukan dengan mengajukan permohonan kepada komite etik dan juga kepada pemerintah. Komisi Etik Fakultas Kedokteran UNPAD (www.kepk.fk. unpad.ac.id) memberikan ijin untuk melakukan penelitian dengan sampel anak. Tim peneliti juga mendapatkan ijin melakukan penelitian dari Dinas Pendidikan dan Kementerian Agama di tingkat Provinsi Jawa Barat untuk melakukan pengambilan data di 267 sekolah dasar yang terpilih secara random dan bersedia untuk ikut berpartisipasi.

Tim peneliti mengirimkan formulir Persetujuan Setelah Penjelasan (PSP) atau 
informed consent kepada orang tua melalui guru. Setelah peneliti mendapatkan PSP yang telah ditandatangani oleh orang tua, peneliti juga menginformasikan kepada anak-anak yang mendapatkan ijin berpartisipasi dari orang tuanya bahwa data mereka akan dijaga kerahasiaannya, dan mereka bebas untuk menjawab ataupun tidak menjawab pertanyaan-pertanyaan.

\section{Alat Ukur}

Children's Worlds (www.isciweb.org) memiliki lima pertanyaan yang mengukur perundungan. Dua pertanyaan mengukur perundungan di rumah yang dilakukan oleh saudara kandung, dan tiga pertanyaan mengukur perundungan yang dilakukan oleh anak lain di sekolah.

Perundungan yang dilakukan oleh saudara kandung diukur melalui frekuensi mengalami perundungan fisik dengan menanyakan, "Selama satu bulan terakhir, seberapa sering kamu mengalami dipukul oleh kakak atau adikmu (tidak termasuk berkelahi atau bermain pukul-pukulan)", perundungan verbal dengan menanyakan, "Selama satu bulan terakhir, seberapa sering kamu mengalami dipanggil/ dijuluki dengan nama yang buruk oleh kakak atau adikmu" (www.isciweb.org).

Perundungan yang dilakukan oleh anak lain di sekolah diukur melalui frekuensi mengalami perundungan fisik dengan menanyakan, "Selama satu bulan terakhir, seberapa sering kamu mengalami dipukul oleh anak-anak lain di sekolahmu (tidak termasuk ketika berkelahi atau bermain pukul-pukulan)", perundungan verbal dengan menanyakan, "Selama satu bulan terakhir, seberapa sering kamu mengalami dipanggil/ dijuluki dengan nama yang buruk oleh anak-anak lain di sekolahmu", dan perundungan psikologis dengan menanyakan, "Selama satu bulan terakhir, seberapa sering kamu dimusuhi/ dikucilkan oleh anak-anak lain di kelasmu" (www.isciweb.org).

Kelima pertanyaan tersebut memiliki 4 pilihan jawaban mengenai frekuensi mengalami perundungan, yaitu $0=$ tidak pernah; 1
= sekali; $2=2$ atau 3 kali; dan $3=$ lebih dari 3 kali.

Versi asli Bahasa Inggris alat ukur perundungan dari Children's Worlds ini telah diterjemahkan ke dalam Bahasa Indonesia dengan mempertimbangkan konteks dan budaya Indonesia (Borualogo, dkk., 2018).

\section{Analisis Data}

Untuk tujuan pemaparan data perundungan, maka data dianalisis dengan menghitung frekuensi terjadinya tiap bentuk perilaku perundungan (fisik, psikologis, dan verbal) di 27 Kota/ Kabupaten pada tiga kelompok umur $(8,10$, dan 12 tahun) dan jenis kelamin. Melalui analisis frekuensi tersebut, maka dapat dipaparkan persentase perundungan yang terjadi di tiap Kota/ Kabupaten.

Data dari 27 Kota/ Kabupaten telah disimpan dan diolah menggunakan SPSS 24. Data frekuensi yang disajikan dalam penelitian ini adalah data awal dari 22.616 sampel anak di 27 Kota/ Kabupaten di Jawa Barat.

\section{Hasil Penelitian dan Pembahasan}

\section{Hasil Penelitian}

Berikut akan dipaparkan data perundungan (fisik, verbal, dan psikologis) pada tiap Kota/ Kabupaten yang dialami oleh anak di rumah dan di sekolah. Untuk dapat memahami data ini dengan baik, perlu disadari bahwa sekecil apapun nilai persentase perundungan yang muncul, namun hal itu tetaplah merupakan nilai yang perlu mendapatkan perhatian serius, karena 1 anak yang melaporkan kejadian perundungan adalah mewakili 26 anak di Jawa Barat, sehingga $1 \%$ angka kejadian adalah mewakili 5.900 anak di Jawa Barat.

Selain itu, perlu pula diperhatikan bahwa pemaparan disajikan dalam skala frekuensi perundungan dari tidak pernah, sekali, 2-3 kali, dan lebih dari 3 kali. Sehingga jika persentase kejadian perundungan ini dikelompokkan menjadi dua kelompok besar, yaitu tidak pernah 
mengalami perundungan dan pernah mengalami perundungan (setidaknya satu kali), maka kita dapat melihat bahwa dari seluruh perilaku perundungan di 27 Kota/ Kabupaten, lebih banyak anak-anak yang melaporkan pernah mengalami perundungan daripada yang tidak pernah mengalami perundungan.

Pemaparan data frekuensi perundungan ini tidak dalam tujuan untuk menunjukkan Kota/ Kabupaten yang lebih baik atau lebih buruk dalam hal angka kejadian perundungan. Pemaparan ini ditujukan agar menjadi perhatian serius bahwa di setiap Kota/ Kabupaten, terjadi perundungan baik di rumah maupun di sekolah, berdasarkan data yang dilaporkan oleh anak-anak yang menjadi korban.

Tabel 2 memperlihatkan bahwa sebagian besar Kota/ Kabupaten memiliki angka kejadian perundungan fisik, bahkan pada beberapa Kota/ Kabupaten, angka kejadian mencapai lebih dari 10\%. Beberapa daerah dengan frekuensi perundungan oleh saudara kandung lebih dari tiga kali untuk wilayah kabupaten adalah Kuningan (20.5\%), Pangandaran (19.6\%), dan Karawang (19.3\%).

Tabel 3 memperlihatkan bahwa dibandingkan dengan perundungan fisik (dipukul oleh saudara kandung), perundungan verbal (dipanggil dengan nama yang buruk oleh saudara kandung) dilaporkan relatif lebih sedikit frekuensi terjadinya. Namun, pada beberapa Kota/ Kabupaten, tetap menunjukkan angka kejadian yang tinggi.

Dibandingkan kejadian perundungan fisik dipukul oleh saudara kandung di rumah, frekuensi kejadian dipukul oleh anak lain di sekolah dilaporkan oleh anak-anak lebih sedikit terjadinya. Namun, pada beberapa Kota/ Kabupaten, angka kejadian ini juga tampak tinggi, seperti misalnya di Kabupaten Pangandaran (17.8\%), Kabupaten Indramayu (17.1\%), Kabupaten Cirebon (16.8\%), Kota Banjar (15.8\%), Kabupaten Karawang (14.3\%), dan Kota Sukabumi (14.0\%) sebagaimana disajikan pada tabel 4.
Tabel 2

Frekuensi Dipukul oleh Saudara Kandung

\begin{tabular}{|c|c|c|c|c|c|}
\hline $\begin{array}{c}\text { Kota/ } \\
\text { Kabupaten }\end{array}$ & $\begin{array}{l}\text { Tidak } \\
\text { pernah }\end{array}$ & Sekali & $\begin{array}{l}2-3 \\
\text { kali }\end{array}$ & $\begin{array}{l}>3 \\
\text { kali }\end{array}$ & Total \\
\hline \multicolumn{6}{|l|}{ Kabupaten } \\
\hline Bogor & $\begin{array}{c}405 \\
(52.0)\end{array}$ & $\begin{array}{c}176 \\
(22.6)\end{array}$ & $\begin{array}{c}80 \\
(10.3)\end{array}$ & $\begin{array}{c}118 \\
(15.1)\end{array}$ & $\begin{array}{c}779 \\
(100)\end{array}$ \\
\hline Sukabumi & $\begin{array}{c}482 \\
(55.8)\end{array}$ & $\begin{array}{c}191 \\
(22.1)\end{array}$ & $\begin{array}{c}90 \\
(10.4)\end{array}$ & $\begin{array}{c}101 \\
(11.7)\end{array}$ & $\begin{array}{c}864 \\
(100)\end{array}$ \\
\hline Cianjur & $\begin{array}{c}361 \\
(56.7)\end{array}$ & $\begin{array}{c}142 \\
(22.3)\end{array}$ & $\begin{array}{c}79 \\
(12.4)\end{array}$ & $\begin{array}{c}55 \\
(8.6)\end{array}$ & $\begin{array}{c}637 \\
(100)\end{array}$ \\
\hline Bandung & $\begin{array}{c}439 \\
(50.3)\end{array}$ & $\begin{array}{c}216 \\
(24.8)\end{array}$ & $\begin{array}{c}101 \\
(11.6)\end{array}$ & $\begin{array}{c}116 \\
(13.3)\end{array}$ & $\begin{array}{c}872 \\
(100)\end{array}$ \\
\hline Garut & $\begin{array}{c}357 \\
(48.4)\end{array}$ & $\begin{array}{c}187 \\
(25.3)\end{array}$ & $\begin{array}{c}112 \\
(15.2)\end{array}$ & $\begin{array}{c}82 \\
(11.1)\end{array}$ & $\begin{array}{c}738 \\
(100)\end{array}$ \\
\hline Tasikmalaya & $\begin{array}{c}329 \\
(52.4)\end{array}$ & $\begin{array}{c}145 \\
(23.1)\end{array}$ & $\begin{array}{c}70 \\
(11.1)\end{array}$ & $\begin{array}{c}84 \\
(13.4)\end{array}$ & $\begin{array}{c}628 \\
(100)\end{array}$ \\
\hline Ciamis & $\begin{array}{c}295 \\
(49.2)\end{array}$ & $\begin{array}{c}145 \\
(24.2)\end{array}$ & $\begin{array}{c}74 \\
(12.4)\end{array}$ & $\begin{array}{c}85 \\
(14.2)\end{array}$ & $\begin{array}{c}599 \\
(100)\end{array}$ \\
\hline Kuningan & $\begin{array}{c}343 \\
(41.4)\end{array}$ & $\begin{array}{c}215 \\
(26.0)\end{array}$ & $\begin{array}{c}100 \\
(12.1)\end{array}$ & $\begin{array}{c}170 \\
(20.5)\end{array}$ & $\begin{array}{c}828 \\
(100)\end{array}$ \\
\hline Cirebo & $\begin{array}{c}494 \\
(55.7)\end{array}$ & $\begin{array}{c}172 \\
(19.4)\end{array}$ & $\begin{array}{c}99 \\
(11.2)\end{array}$ & $\begin{array}{c}122 \\
(13.8)\end{array}$ & $\begin{array}{c}887 \\
(100)\end{array}$ \\
\hline Majalengka & $\begin{array}{c}366 \\
(54.1)\end{array}$ & $\begin{array}{c}160 \\
(23.6)\end{array}$ & $\begin{array}{c}71 \\
(10.5)\end{array}$ & $\begin{array}{c}80 \\
(11.8)\end{array}$ & $\begin{array}{c}677 \\
(100)\end{array}$ \\
\hline Sumed & $\begin{array}{c}445 \\
(60.4)\end{array}$ & & $\begin{array}{c}64 \\
(8.7)\end{array}$ & $\begin{array}{c}92 \\
(12.5)\end{array}$ & $\begin{array}{c}737 \\
(100)\end{array}$ \\
\hline Indran & $\begin{array}{c}343 \\
(51.9)\end{array}$ & & $\begin{array}{c}89 \\
(13.5)\end{array}$ & $\begin{array}{c}86 \\
(13.0)\end{array}$ & $\begin{array}{c}661 \\
(100)\end{array}$ \\
\hline Subang & $\begin{array}{c}341 \\
(51.9)\end{array}$ & & $\begin{array}{c}62 \\
(9.4)\end{array}$ & $\begin{array}{c}94 \\
(14.3)\end{array}$ & $\begin{array}{c}657 \\
(100)\end{array}$ \\
\hline Purwakarta & $\begin{array}{c}471 \\
(51.0)\end{array}$ & $\begin{array}{c}208 \\
(22.5)\end{array}$ & $\begin{array}{c}135 \\
(14.6)\end{array}$ & $\begin{array}{c}109 \\
(11.8)\end{array}$ & $\begin{array}{c}923 \\
(100)\end{array}$ \\
\hline Karaw & $\begin{array}{c}419 \\
(46.0)\end{array}$ & $\begin{array}{c}225 \\
(24.7)\end{array}$ & $\begin{array}{c}90 \\
(9.9)\end{array}$ & $\begin{array}{c}176 \\
(19.3)\end{array}$ & $\begin{array}{c}910 \\
(100)\end{array}$ \\
\hline Bekasi & $\begin{array}{c}408 \\
(58.3)\end{array}$ & $\begin{array}{c}152 \\
(21.7)\end{array}$ & $\begin{array}{c}67 \\
(9.6)\end{array}$ & $\begin{array}{c}73 \\
(10.4)\end{array}$ & $\begin{array}{l}700 \\
(100)\end{array}$ \\
\hline $\begin{array}{l}\text { Bandung } \\
\text { Barat }\end{array}$ & $\begin{array}{c}338 \\
(55.0)\end{array}$ & & $\begin{array}{c}58 \\
(9.4)\end{array}$ & $\begin{array}{c}71 \\
(11.5)\end{array}$ & $\begin{array}{c}615 \\
(100)\end{array}$ \\
\hline Pangandc & $\begin{array}{c}268 \\
(47.3)\end{array}$ & $\begin{array}{c}120 \\
(21.2)\end{array}$ & $\begin{array}{c}68 \\
(12.0)\end{array}$ & $\begin{array}{c}111 \\
(19.6)\end{array}$ & $\begin{array}{c}567 \\
(100)\end{array}$ \\
\hline \multicolumn{6}{|l|}{ Kota } \\
\hline Porre & $\begin{array}{c}557 \\
(42.3)\end{array}$ & $\begin{array}{c}364 \\
(27.7)\end{array}$ & $\begin{array}{c}146 \\
(11.1)\end{array}$ & $\begin{array}{c}249 \\
(18.9)\end{array}$ & $\begin{array}{l}1316 \\
(100)\end{array}$ \\
\hline Sukab & $\begin{array}{c}310 \\
(44.2)\end{array}$ & $\begin{array}{c}178 \\
(25.4)\end{array}$ & $\begin{array}{c}84 \\
(12.0)\end{array}$ & $\begin{array}{c}130 \\
(18.5)\end{array}$ & $\begin{array}{c}702 \\
(100)\end{array}$ \\
\hline Bandu & $\begin{array}{c}515 \\
(43.5)\end{array}$ & $\begin{array}{c}290 \\
(24.5)\end{array}$ & $\begin{array}{c}119 \\
(10.1)\end{array}$ & $\begin{array}{c}260 \\
(22.0)\end{array}$ & $\begin{array}{l}1184 \\
(100)\end{array}$ \\
\hline Cirebc & $\begin{array}{c}283 \\
(34.5)\end{array}$ & $\begin{array}{c}217 \\
(26.4)\end{array}$ & $\begin{array}{c}116 \\
(14.1)\end{array}$ & $\begin{array}{c}205 \\
(25.0)\end{array}$ & $\begin{array}{c}821 \\
(100)\end{array}$ \\
\hline Bekasi & $\begin{array}{c}292 \\
(42.7)\end{array}$ & $\begin{array}{c}178 \\
(26.0)\end{array}$ & $\begin{array}{c}82 \\
(12.0)\end{array}$ & $\begin{array}{c}132 \\
(19.3)\end{array}$ & $\begin{array}{c}684 \\
(100)\end{array}$ \\
\hline Depok & $\begin{array}{c}484 \\
(40.7)\end{array}$ & $\begin{array}{c}304 \\
(25.5)\end{array}$ & $\begin{array}{c}132 \\
(11.1)\end{array}$ & $\begin{array}{c}270 \\
(22.7)\end{array}$ & $\begin{array}{l}1190 \\
(100)\end{array}$ \\
\hline Cimahi & $\begin{array}{c}528 \\
(47.2)\end{array}$ & $\begin{array}{c}262 \\
(23.4)\end{array}$ & $\begin{array}{c}122 \\
(10.9)\end{array}$ & $\begin{array}{c}207 \\
(18.5)\end{array}$ & $\begin{array}{l}1119 \\
(100)\end{array}$ \\
\hline Tasikm & $\begin{array}{c}328 \\
(42.1)\end{array}$ & $\begin{array}{c}213 \\
(27.3)\end{array}$ & $\begin{array}{c}109 \\
(14.0)\end{array}$ & $\begin{array}{c}130 \\
(16.7)\end{array}$ & $\begin{array}{c}780 \\
(100)\end{array}$ \\
\hline Banjar & $\begin{array}{c}332 \\
(52.0)\end{array}$ & $\begin{array}{c}153 \\
(23.9)\end{array}$ & $\begin{array}{c}72 \\
(11.3)\end{array}$ & $\begin{array}{c}82 \\
(12.8)\end{array}$ & $\begin{array}{c}639 \\
(100)\end{array}$ \\
\hline
\end{tabular}


Tabel 3

Frekuensi Dipanggil dengan Nama yang Buruk oleh Saudara Kandung

\begin{tabular}{|c|c|c|c|c|c|}
\hline $\begin{array}{c}\text { Kota/ } \\
\text { Kabupaten }\end{array}$ & $\begin{array}{l}\text { Tidak } \\
\text { pernah }\end{array}$ & Sekali & $\begin{array}{l}2-3 \\
\text { kali }\end{array}$ & $\begin{array}{l}>3 \\
\text { kali }\end{array}$ & Total \\
\hline \multicolumn{6}{|l|}{ Kabupaten } \\
\hline Bogor & $\begin{array}{c}440 \\
(61.9)\end{array}$ & $\begin{array}{c}146 \\
(20.5)\end{array}$ & $\begin{array}{c}55 \\
(7.7)\end{array}$ & $\begin{array}{c}70 \\
(9.8)\end{array}$ & $\begin{array}{c}711 \\
(100)\end{array}$ \\
\hline Sukabumi & $\begin{array}{c}459 \\
(59.1)\end{array}$ & $\begin{array}{c}175 \\
(22.6)\end{array}$ & $\begin{array}{c}87 \\
(11.2)\end{array}$ & $\begin{array}{c}55 \\
(7.1)\end{array}$ & $\begin{array}{c}776 \\
(100)\end{array}$ \\
\hline Cianjur & $\begin{array}{c}370 \\
(65.6)\end{array}$ & $\begin{array}{c}112 \\
(19.9)\end{array}$ & $\begin{array}{c}38 \\
(6.7)\end{array}$ & $\begin{array}{c}44 \\
(7.8)\end{array}$ & $\begin{array}{c}564 \\
(100)\end{array}$ \\
\hline Bandung & $\begin{array}{c}490 \\
(59.8)\end{array}$ & $\begin{array}{c}186 \\
(22.7)\end{array}$ & $\begin{array}{c}77 \\
(9.4)\end{array}$ & $\begin{array}{c}66 \\
(8.1)\end{array}$ & $\begin{array}{c}819 \\
(100)\end{array}$ \\
\hline Garut & $\begin{array}{c}392 \\
(58.0)\end{array}$ & $\begin{array}{c}158 \\
(23.4)\end{array}$ & $\begin{array}{c}67 \\
(9.9)\end{array}$ & $\begin{array}{c}59 \\
(8.7)\end{array}$ & $\begin{array}{c}676 \\
(100)\end{array}$ \\
\hline Tasikmalaya & $\begin{array}{c}370 \\
(61.1)\end{array}$ & $\begin{array}{c}141 \\
(23.3)\end{array}$ & $\begin{array}{c}51 \\
(8.4)\end{array}$ & $\begin{array}{c}44 \\
(7.3)\end{array}$ & $\begin{array}{c}606 \\
(100)\end{array}$ \\
\hline Ciamis & $\begin{array}{c}358 \\
(61.6)\end{array}$ & $\begin{array}{c}125 \\
(21.5)\end{array}$ & $\begin{array}{c}46 \\
(7.9)\end{array}$ & $\begin{array}{c}52 \\
(9.0)\end{array}$ & $\begin{array}{c}581 \\
(100)\end{array}$ \\
\hline Kuningan & $\begin{array}{c}454 \\
(56.8)\end{array}$ & $\begin{array}{c}163 \\
(20.4)\end{array}$ & $\begin{array}{c}71 \\
(8.9)\end{array}$ & $\begin{array}{c}112 \\
(14.0)\end{array}$ & $\begin{array}{c}800 \\
(100)\end{array}$ \\
\hline Cirebon & $\begin{array}{c}434 \\
(53.7)\end{array}$ & $\begin{array}{c}193 \\
(23.9)\end{array}$ & $\begin{array}{c}86 \\
(10.6)\end{array}$ & $\begin{array}{c}95 \\
(11.8)\end{array}$ & $\begin{array}{c}808 \\
(100)\end{array}$ \\
\hline Majalengka & $\begin{array}{c}427 \\
(66.5)\end{array}$ & $\begin{array}{c}110 \\
(17.1)\end{array}$ & $\begin{array}{c}63 \\
(9.8)\end{array}$ & $\begin{array}{c}42 \\
(6.5)\end{array}$ & $\begin{array}{c}642 \\
(100)\end{array}$ \\
\hline Sumedang & $\begin{array}{c}438 \\
(66.5)\end{array}$ & $\begin{array}{c}117 \\
(17.8)\end{array}$ & $\begin{array}{c}54 \\
(8.2)\end{array}$ & $\begin{array}{c}50 \\
(7.6)\end{array}$ & $\begin{array}{c}659 \\
(100)\end{array}$ \\
\hline Indramayu & $\begin{array}{c}320 \\
(54.0)\end{array}$ & $\begin{array}{c}140 \\
(23.6)\end{array}$ & $\begin{array}{c}71 \\
(12.0)\end{array}$ & $\begin{array}{c}62 \\
(10.5)\end{array}$ & $\begin{array}{c}593 \\
(100)\end{array}$ \\
\hline Subang & $\begin{array}{c}329 \\
(55.3)\end{array}$ & $\begin{array}{c}130 \\
(21.8)\end{array}$ & $\begin{array}{c}68 \\
(11.4)\end{array}$ & $\begin{array}{c}68 \\
(11.4)\end{array}$ & $\begin{array}{c}595 \\
(100)\end{array}$ \\
\hline Purwakarta & $\begin{array}{c}528 \\
(60.8)\end{array}$ & $\begin{array}{c}161 \\
(18.5)\end{array}$ & $\begin{array}{c}68 \\
(7.8)\end{array}$ & $\begin{array}{c}112 \\
(12.9)\end{array}$ & $\begin{array}{c}869 \\
(100)\end{array}$ \\
\hline Karawang & $\begin{array}{c}551 \\
(64.1)\end{array}$ & $\begin{array}{c}142 \\
(16.5)\end{array}$ & $\begin{array}{c}64 \\
(7.5)\end{array}$ & $\begin{array}{c}102 \\
(11.9)\end{array}$ & $\begin{array}{c}859 \\
(100)\end{array}$ \\
\hline Bekasi & $\begin{array}{c}451 \\
(67.7)\end{array}$ & $\begin{array}{c}119 \\
(17.8)\end{array}$ & $\begin{array}{c}60 \\
(9.0)\end{array}$ & $\begin{array}{c}37 \\
(5.5)\end{array}$ & $\begin{array}{c}667 \\
(100)\end{array}$ \\
\hline Bandung & 381 & 105 & 39 & 45 & 570 \\
\hline $\begin{array}{l}\text { Barat } \\
\text { Pangandaran }\end{array}$ & $\begin{array}{c}(66.8) \\
309\end{array}$ & $\begin{array}{c}(18.4) \\
108\end{array}$ & $\begin{array}{c}(6.8) \\
51\end{array}$ & $\begin{array}{c}(7.9) \\
60\end{array}$ & $\begin{array}{c}(100) \\
528\end{array}$ \\
\hline & $(58.5)$ & $(20.5)$ & $(9.7)$ & (11.4) & (100) \\
\hline Kota & & & & & \\
\hline Bogor & $\begin{array}{c}810 \\
(63.2)\end{array}$ & $\begin{array}{c}258 \\
(20.1)\end{array}$ & $\begin{array}{c}74 \\
(5.8)\end{array}$ & $\begin{array}{c}140 \\
(10.9)\end{array}$ & $\begin{array}{l}1282 \\
(100)\end{array}$ \\
\hline Sukabumi & $\begin{array}{c}381 \\
(57.7)\end{array}$ & $\begin{array}{c}153 \\
(23.2)\end{array}$ & $\begin{array}{c}58 \\
(8.8)\end{array}$ & $\begin{array}{c}68 \\
(10.3)\end{array}$ & $\begin{array}{c}660 \\
(100)\end{array}$ \\
\hline Bandung & $\begin{array}{c}695 \\
(59.4)\end{array}$ & $\begin{array}{c}247 \\
(21.1)\end{array}$ & $\begin{array}{c}79 \\
(6.8)\end{array}$ & $\begin{array}{c}149 \\
(12.7)\end{array}$ & $\begin{array}{l}1.170 \\
(100)\end{array}$ \\
\hline Cirebon & $\begin{array}{c}479 \\
(61.2)\end{array}$ & $\begin{array}{c}151 \\
(19.3)\end{array}$ & $\begin{array}{c}55 \\
(7.0)\end{array}$ & $\begin{array}{c}98 \\
(12.5)\end{array}$ & $\begin{array}{c}783 \\
(100)\end{array}$ \\
\hline Bekasi & $\begin{array}{c}422 \\
(64.3)\end{array}$ & $\begin{array}{c}128 \\
(19.5)\end{array}$ & $\begin{array}{c}46 \\
(7.0)\end{array}$ & $\begin{array}{c}60 \\
(9.1)\end{array}$ & $\begin{array}{c}656 \\
(100)\end{array}$ \\
\hline Depok & $\begin{array}{c}729 \\
(62.5)\end{array}$ & $\begin{array}{c}210 \\
(18.0)\end{array}$ & $\begin{array}{c}95 \\
(8.1)\end{array}$ & $\begin{array}{c}132 \\
(11.3)\end{array}$ & $\begin{array}{l}1.166 \\
(100)\end{array}$ \\
\hline Cimahi & $\begin{array}{c}697 \\
(63.6)\end{array}$ & $\begin{array}{c}216 \\
(19.7)\end{array}$ & $\begin{array}{c}69 \\
(6.3)\end{array}$ & $\begin{array}{c}114 \\
(10.4)\end{array}$ & $\begin{array}{l}1.096 \\
(100)\end{array}$ \\
\hline Tasikmalaya & $\begin{array}{c}436 \\
(57.4)\end{array}$ & $\begin{array}{c}179 \\
(23.6)\end{array}$ & $\begin{array}{c}62 \\
(8.2)\end{array}$ & $\begin{array}{c}83 \\
(10.9)\end{array}$ & $\begin{array}{c}760 \\
(100)\end{array}$ \\
\hline Banjar & $\begin{array}{c}388 \\
(62.5)\end{array}$ & $\begin{array}{c}128 \\
(20.6)\end{array}$ & $\begin{array}{c}38 \\
(6.1)\end{array}$ & $\begin{array}{c}67 \\
(10.8)\end{array}$ & $\begin{array}{c}621 \\
(100)\end{array}$ \\
\hline
\end{tabular}

Tabel 4

Frekuensi Dipukul oleh Anak Lain di Sekolah

\begin{tabular}{|c|c|c|c|c|c|}
\hline $\begin{array}{c}\text { Kota/ } \\
\text { Kabupaten }\end{array}$ & $\begin{array}{c}\text { Tidak } \\
\text { pernah }\end{array}$ & Sekali & $\begin{array}{l}2-3 \\
\text { kali }\end{array}$ & $\begin{array}{l}>3 \\
\text { kali }\end{array}$ & Total \\
\hline \multicolumn{6}{|l|}{ Kabupaten } \\
\hline Bogor & $\begin{array}{c}362 \\
(48.3)\end{array}$ & $\begin{array}{c}195 \\
(26.0)\end{array}$ & $\begin{array}{c}113 \\
(15.1)\end{array}$ & $\begin{array}{c}80 \\
(10.7)\end{array}$ & $\begin{array}{c}750 \\
(100)\end{array}$ \\
\hline Sukabumi & $\begin{array}{c}394 \\
(47.5)\end{array}$ & $\begin{array}{c}213 \\
(25.7)\end{array}$ & $\begin{array}{c}124 \\
(14.9)\end{array}$ & $\begin{array}{c}99 \\
(11.9)\end{array}$ & $\begin{array}{c}830 \\
(100)\end{array}$ \\
\hline Cianjur & $\begin{array}{c}303 \\
(49.3)\end{array}$ & $\begin{array}{c}161 \\
(26.2)\end{array}$ & $\begin{array}{c}81 \\
(13.2)\end{array}$ & $\begin{array}{c}69 \\
(11.2)\end{array}$ & $\begin{array}{c}614 \\
(100)\end{array}$ \\
\hline Bandung & $\begin{array}{c}406 \\
(48.0)\end{array}$ & $\begin{array}{c}246 \\
(29.1)\end{array}$ & $\begin{array}{c}120 \\
(14.2)\end{array}$ & $\begin{array}{c}73 \\
(8.6)\end{array}$ & $\begin{array}{c}845 \\
(100)\end{array}$ \\
\hline Garut & $\begin{array}{c}328 \\
(45.8)\end{array}$ & $\begin{array}{c}216 \\
(30.2)\end{array}$ & $\begin{array}{c}95 \\
(13.3)\end{array}$ & $\begin{array}{c}77 \\
(10.8)\end{array}$ & $\begin{array}{c}716 \\
(100)\end{array}$ \\
\hline Tasikmalaya & $\begin{array}{c}273 \\
(45.3)\end{array}$ & $\begin{array}{c}168 \\
(27.9)\end{array}$ & $\begin{array}{c}82 \\
(13.6)\end{array}$ & $\begin{array}{c}79 \\
(13.1)\end{array}$ & $\begin{array}{c}602 \\
(100)\end{array}$ \\
\hline Ciamis & $\begin{array}{c}261 \\
(43.8)\end{array}$ & $\begin{array}{c}165 \\
(27.7)\end{array}$ & $\begin{array}{c}88 \\
(14.8)\end{array}$ & $\begin{array}{c}82 \\
(13.8)\end{array}$ & $\begin{array}{c}596 \\
(100)\end{array}$ \\
\hline Kuningan & $\begin{array}{c}387 \\
(49.5)\end{array}$ & $\begin{array}{c}171 \\
(21.9)\end{array}$ & $\begin{array}{c}133 \\
(17.0)\end{array}$ & $\begin{array}{c}91 \\
(11.6)\end{array}$ & $\begin{array}{c}782 \\
(100)\end{array}$ \\
\hline Cirebon & $\begin{array}{c}359 \\
(42.4)\end{array}$ & $\begin{array}{c}211 \\
(24.9)\end{array}$ & $\begin{array}{c}135 \\
(15.9)\end{array}$ & $\begin{array}{c}142 \\
(16.8)\end{array}$ & $\begin{array}{l}847 \\
(100)\end{array}$ \\
\hline Majalengka & $\begin{array}{c}321 \\
(47.2)\end{array}$ & $\begin{array}{c}172 \\
(25.3)\end{array}$ & $\begin{array}{c}100 \\
(14.7)\end{array}$ & $\begin{array}{c}87 \\
(12.8)\end{array}$ & $\begin{array}{c}680 \\
(100)\end{array}$ \\
\hline Sumedang & $\begin{array}{c}383 \\
(54.0)\end{array}$ & $\begin{array}{c}165 \\
(23.3)\end{array}$ & $\begin{array}{c}79 \\
(11.1)\end{array}$ & $\begin{array}{c}82 \\
(11.6)\end{array}$ & $\begin{array}{c}709 \\
(100)\end{array}$ \\
\hline Indramayu & $\begin{array}{c}283 \\
(43.3)\end{array}$ & $\begin{array}{c}151 \\
(23.1)\end{array}$ & $\begin{array}{c}108 \\
(16.5)\end{array}$ & $\begin{array}{c}112 \\
(17.1)\end{array}$ & $\begin{array}{c}654 \\
(100)\end{array}$ \\
\hline Subang & $\begin{array}{c}297 \\
(47.4)\end{array}$ & $\begin{array}{c}152 \\
(24.3)\end{array}$ & $\begin{array}{c}92 \\
(14.7)\end{array}$ & $\begin{array}{c}85 \\
(13.6)\end{array}$ & $\begin{array}{l}626 \\
(100)\end{array}$ \\
\hline Purwakarta & $\begin{array}{c}435 \\
(48.7)\end{array}$ & $\begin{array}{c}195 \\
(21.8)\end{array}$ & $\begin{array}{c}140 \\
(15.7)\end{array}$ & $\begin{array}{c}124 \\
(13.9)\end{array}$ & $\begin{array}{c}894 \\
(100)\end{array}$ \\
\hline Karawang & $\begin{array}{c}412 \\
(46.4)\end{array}$ & $\begin{array}{c}233 \\
(26.2)\end{array}$ & $\begin{array}{c}116 \\
(13.1)\end{array}$ & $\begin{array}{c}127 \\
(14.3)\end{array}$ & $\begin{array}{l}888 \\
(100)\end{array}$ \\
\hline Bekasi & $\begin{array}{c}344 \\
(50.6)\end{array}$ & $\begin{array}{c}172 \\
(25.3)\end{array}$ & $\begin{array}{c}90 \\
(13.2)\end{array}$ & $\begin{array}{c}74 \\
(10.9)\end{array}$ & $\begin{array}{c}680 \\
(100)\end{array}$ \\
\hline $\begin{array}{l}\text { Bandung } \\
\text { Barat }\end{array}$ & $\begin{array}{c}288 \\
(49.6)\end{array}$ & $\begin{array}{c}141 \\
(24.3)\end{array}$ & $\begin{array}{c}80 \\
(13.8)\end{array}$ & $\begin{array}{c}72 \\
(12.4)\end{array}$ & $\begin{array}{c}581 \\
(100)\end{array}$ \\
\hline Pangandaran & $\begin{array}{c}220 \\
(40.0)\end{array}$ & $\begin{array}{c}157 \\
(28.5)\end{array}$ & $\begin{array}{c}75 \\
(13.6)\end{array}$ & $\begin{array}{c}98 \\
(17.8)\end{array}$ & $\begin{array}{c}550 \\
(100)\end{array}$ \\
\hline Kota & & & & & \\
\hline Bogor & $\begin{array}{c}612 \\
(47.2)\end{array}$ & $\begin{array}{c}325 \\
(25.1)\end{array}$ & $\begin{array}{c}204 \\
(15.7)\end{array}$ & $\begin{array}{c}156 \\
(12.0)\end{array}$ & $\begin{array}{l}1.297 \\
(100)\end{array}$ \\
\hline Sukabumi & $\begin{array}{c}293 \\
(43.7)\end{array}$ & $\begin{array}{c}190 \\
(28.3)\end{array}$ & $\begin{array}{c}94 \\
(14.0)\end{array}$ & $\begin{array}{c}94 \\
(14.0)\end{array}$ & $\begin{array}{c}671 \\
(100)\end{array}$ \\
\hline Bandung & $\begin{array}{c}586 \\
(51.1)\end{array}$ & $\begin{array}{c}262 \\
(22.8)\end{array}$ & $\begin{array}{c}153 \\
(13.3)\end{array}$ & $\begin{array}{c}146 \\
(12.7)\end{array}$ & $\begin{array}{l}1.147 \\
(100)\end{array}$ \\
\hline Cirebon & $\begin{array}{c}331 \\
(42.1)\end{array}$ & $\begin{array}{c}212 \\
(26.9)\end{array}$ & $\begin{array}{c}139 \\
(17.7)\end{array}$ & $\begin{array}{c}105 \\
(13.3)\end{array}$ & $\begin{array}{c}787 \\
(100)\end{array}$ \\
\hline Bekasi & $\begin{array}{c}346 \\
(53.0)\end{array}$ & $\begin{array}{c}149 \\
(22.8)\end{array}$ & $\begin{array}{c}82 \\
(12.6)\end{array}$ & $\begin{array}{c}76 \\
(11.6)\end{array}$ & $\begin{array}{c}653 \\
(100)\end{array}$ \\
\hline Depok & $\begin{array}{c}561 \\
(48.4)\end{array}$ & $\begin{array}{c}305 \\
(26.3)\end{array}$ & $\begin{array}{c}151 \\
(13.0)\end{array}$ & $\begin{array}{c}143 \\
(12.3)\end{array}$ & $\begin{array}{l}1.160 \\
(100)\end{array}$ \\
\hline Cimahi & $\begin{array}{c}568 \\
(51.8)\end{array}$ & $\begin{array}{c}268 \\
(24.4)\end{array}$ & $\begin{array}{c}151 \\
(13.8)\end{array}$ & $\begin{array}{c}110 \\
(10.0)\end{array}$ & $\begin{array}{l}1.097 \\
(100)\end{array}$ \\
\hline Tasikmalaya & $\begin{array}{c}367 \\
(48.6)\end{array}$ & $\begin{array}{c}181 \\
(24.0)\end{array}$ & $\begin{array}{c}117 \\
(15.5)\end{array}$ & $\begin{array}{c}90 \\
(11.9)\end{array}$ & $\begin{array}{c}755 \\
(100)\end{array}$ \\
\hline Banjar & $\begin{array}{c}268 \\
(42.5)\end{array}$ & $\begin{array}{c}171 \\
(27.1)\end{array}$ & $\begin{array}{c}92 \\
(14.6)\end{array}$ & $\begin{array}{c}100 \\
(15.8)\end{array}$ & $\begin{array}{c}631 \\
(100)\end{array}$ \\
\hline
\end{tabular}


Tabel 5 memperlihatkan bahwa anak melaporkan persentase frekuensi perundungan verbal (dipanggil dengan nama yang buruk oleh anak lain di sekolah) tergolong tinggi di hampir semua Kota/ Kabupaten. Hal ini menunjukkan bahwa angka kejadian perundungan verbal ini banyak terjadi. Bahkan di beberapa daerah mencapai angka lebih dari 23\% untuk frekuensi kejadian lebih dari 3 kali (Pangandaran, Karawang, Cirebon, Majalengka, dan Sumedang).

Tabel 6 memperlihatkan bahwa anak melaporkan cukup tingginya angka perundungan psikologis (dikucilkan oleh anak lain di kelas). Namun informasi lain yang disajikan dalam tabel 6 tersebut menunjukkan data bahwa tidak ada daerah baik di kota ataupun kabupaten di Jawa Barat yang melebihi $20 \%$, terutama untuk kejadian yang terjadi lebih dari tiga kali. Hal tersebut berbeda dengan kasus perundungan lainnya yang menunjukkan angka lebih dari $20 \%$ untuk beberapa daerah tersebut. Data pada tabel 6 juga menunjukkan persentase yang tinggi untuk mereka yang tidak pernah mendapatkan kasus perundungan, artinya kasus ini masih sedikit terjadi di hampir semua wilayah di Jawa Barat.

Berdasarkan laporan anak, tabel 7 memperlihatkan bahwa dari kelima perilaku perundungan di rumah dan di sekolah, perundungan fisik di rumah dan perundungan verbal di sekolah merupakan jenis yang memiliki angka kejadian paling tinggi. Data kasus perundungan yang paling banyak terjadi atau umumnya lebih dari tiga kali adalah perundungan yang dilakukan oleh teman lain di sekolah dengan memanggil nama buruk anak bersangkutan. Kasus perundungan dengan dipanggil buruk oleh teman lain di sekolah ini mencapai $20 \%$. Jika dibandingkan dengan kasus lainnya yang terjadi lebih dari tiga kali, maka kasus perundungan dengan dipanggil buruk oleh teman lain tersebut termasuk sangat tinggi dan bahkan sering terjadi hampir di seluruh wilayah di Jawa Barat.
Tabel 5

Frekuensi Dipanggil dengan Nama yang Buruk oleh Anak Lain di Sekolah

\begin{tabular}{|c|c|c|c|c|c|}
\hline $\begin{array}{c}\text { Kota/ } \\
\text { Kabupaten }\end{array}$ & $\begin{array}{c}\text { Tidak } \\
\text { pernah }\end{array}$ & Sekali & $\begin{array}{l}2-3 \\
\text { kali }\end{array}$ & $\begin{array}{r}>3 \\
\text { kali }\end{array}$ & Total \\
\hline \multicolumn{6}{|l|}{ Kabupaten } \\
\hline \multirow[t]{2}{*}{ Bogor } & 322 & 161 & 120 & 135 & 738 \\
\hline & 43.6 & 21.8 & 16.3 & 18.3 & 100 \\
\hline \multirow[t]{2}{*}{ Sukabumi } & 302 & 224 & 153 & 137 & 816 \\
\hline & 37.0 & 27.5 & 18.8 & 16.8 & 100 \\
\hline \multirow[t]{2}{*}{ Cianjur } & 257 & 128 & 92 & 112 & 589 \\
\hline & 43.6 & 21.7 & 15.6 & 19.0 & 100 \\
\hline \multirow[t]{2}{*}{ Bandung } & 322 & 206 & 139 & 169 & 836 \\
\hline & 38.5 & 24.6 & 16.6 & 20.2 & 100 \\
\hline \multirow[t]{2}{*}{ Garut } & 291 & 175 & 131 & 114 & 711 \\
\hline & 40.9 & 24.6 & 18.4 & 16.0 & 100 \\
\hline \multirow[t]{2}{*}{ Tasikmalaya } & 220 & 151 & 99 & 138 & 608 \\
\hline & 36.2 & 24.8 & 16.3 & 22.7 & 100 \\
\hline \multirow[t]{2}{*}{ Ciamis } & 221 & 130 & 111 & 138 & 600 \\
\hline & 36.8 & 21.7 & 18.5 & 23.0 & 100 \\
\hline \multirow[t]{2}{*}{ Kuningan } & 291 & 189 & 141 & 179 & 800 \\
\hline & 36.4 & 23.6 & 17.6 & 22.4 & 100 \\
\hline \multirow[t]{2}{*}{ Cirebon } & 288 & 212 & 131 & 196 & 827 \\
\hline & 34.8 & 25.6 & 15.8 & 23.7 & 100 \\
\hline \multirow[t]{2}{*}{ Majalengka } & 249 & 145 & 103 & 155 & 652 \\
\hline & 38.2 & 22.2 & 15.8 & 23.8 & 100 \\
\hline \multirow[t]{2}{*}{ Sumedang } & 272 & 156 & 104 & 167 & 699 \\
\hline & 38.9 & 22.3 & 14.9 & 23.9 & 100 \\
\hline \multirow[t]{2}{*}{ Indramayu } & 220 & 155 & 115 & 1135 & 625 \\
\hline & 35.2 & 24.8 & 18.4 & 21.6 & 100 \\
\hline \multirow[t]{2}{*}{ Subang } & 229 & 141 & 101 & 121 & 592 \\
\hline & 38.7 & 23.8 & 17.1 & 20.4 & 100 \\
\hline \multirow[t]{2}{*}{ Purwakarta } & 313 & 256 & 141 & 168 & 878 \\
\hline & 35.6 & 29.2 & 16.1 & 19.1 & 100 \\
\hline \multirow[t]{2}{*}{ Karawang } & 328 & 195 & 130 & 216 & 869 \\
\hline & 37.7 & 22.4 & 15.0 & 24.9 & 100 \\
\hline \multirow[t]{2}{*}{ Bekasi } & 346 & 154 & 80 & 101 & 681 \\
\hline & 50.8 & 22.6 & 11.7 & 14.8 & 100 \\
\hline Bandung & 236 & 144 & 105 & 88 & 573 \\
\hline \multirow{3}{*}{$\begin{array}{l}\text { Barat } \\
\text { Pangandaran }\end{array}$} & 41.2 & 25.1 & 18.3 & 15.4 & 100 \\
\hline & 190 & 117 & 88 & 149 & 544 \\
\hline & 34.9 & 21.5 & 16.2 & 27.4 & 100 \\
\hline Kota & & & & & \\
\hline Bogor & 569 & 282 & 188 & 250 & 1.289 \\
\hline & 44.1 & 21.9 & 14.6 & 19.4 & 100 \\
\hline Sukabumi & 223 & 180 & 92 & 165 & 660 \\
\hline & 33.8 & 27.3 & 13.9 & 25.0 & 100 \\
\hline Bandung & 451 & 277 & 181 & 258 & 1.167 \\
\hline & 38.6 & 23.7 & 15.5 & 22.1 & 100 \\
\hline Cirebon & 315 & 182 & 123 & 182 & 802 \\
\hline & 39.3 & 22.7 & 15.3 & 22.7 & 100 \\
\hline Bekasi & 307 & 150 & 93 & 113 & 663 \\
\hline & 46.3 & 22.6 & 14.0 & 17.0 & 100 \\
\hline Depok & 509 & 251 & 151 & 248 & 1.159 \\
\hline & 43.9 & 21.7 & 13.0 & 21.4 & 100 \\
\hline Cimahi & 435 & 279 & 171 & 218 & 1.103 \\
\hline & 39.4 & 25.3 & 15.5 & 19.8 & 100 \\
\hline Tasikmalaya & 282 & 196 & 124 & 159 & 761 \\
\hline & 37.1 & 25.8 & 16.3 & 20.9 & 100 \\
\hline Banjar & 233 & 141 & 92 & 150 & 616 \\
\hline & 37.8 & 22.9 & 14.9 & 24.4 & 100 \\
\hline
\end{tabular}


Tabel 6

Frekuensi Dikucilkan oleh Anak Lain di Kelas

\begin{tabular}{|c|c|c|c|c|c|}
\hline $\begin{array}{c}\text { Kota/ } \\
\text { Kabupaten }\end{array}$ & $\begin{array}{r}\text { Tidak } \\
\text { pernah }\end{array}$ & Sekali & $\begin{array}{l}2-3 \\
\text { kali }\end{array}$ & $\begin{array}{l}>3 \\
\text { kali }\end{array}$ & Total \\
\hline \multicolumn{6}{|l|}{ Kabupaten } \\
\hline \multirow{2}{*}{ Bogor } & 379 & 169 & 119 & 71 & 738 \\
\hline & 51.4 & 22.9 & 16.1 & 9.6 & 100 \\
\hline \multirow[t]{2}{*}{ Sukabumi } & 398 & 158 & 147 & 87 & 790 \\
\hline & 50.4 & 20.2 & 18.6 & 11.0 & 100 \\
\hline \multirow[t]{2}{*}{ Cianjur } & 271 & 133 & 107 & 72 & 583 \\
\hline & 46.5 & 22.8 & 18.4 & 12.3 & 100 \\
\hline \multirow[t]{2}{*}{ Bandung } & 384 & 214 & 117 & 69 & 784 \\
\hline & 49.0 & 27.3 & 14.9 & 8.8 & 100 \\
\hline \multirow[t]{2}{*}{ Garut } & 326 & 142 & 121 & 82 & 671 \\
\hline & 48.6 & 21.2 & 18.0 & 12.2 & 100 \\
\hline \multirow[t]{2}{*}{ Tasikmalaya } & 302 & 142 & 76 & 70 & 590 \\
\hline & 51.2 & 24.1 & 12.9 & 11.9 & 100 \\
\hline \multirow[t]{2}{*}{ Ciamis } & 301 & 136 & 64 & 76 & 577 \\
\hline & 52.2 & 23.6 & 11.1 & 13.2 & 100 \\
\hline \multirow[t]{2}{*}{ Kuningan } & 378 & 175 & 103 & 114 & 770 \\
\hline & 49.1 & 22.7 & 13.4 & 14.8 & 100 \\
\hline \multirow[t]{2}{*}{ Cirebon } & 339 & 209 & 135 & 133 & 816 \\
\hline & 41.5 & 25.6 & 16.5 & 16.3 & 100 \\
\hline \multirow[t]{2}{*}{ Majalengka } & 327 & 149 & 88 & 79 & 643 \\
\hline & 50.9 & 23.2 & 13.7 & 12.3 & 100 \\
\hline \multirow[t]{2}{*}{ Sumedang } & 359 & 145 & 75 & 92 & 671 \\
\hline & 53.5 & 21.6 & 11.2 & 13.7 & 100 \\
\hline \multirow[t]{2}{*}{ Indramayu } & 244 & 177 & 92 & 120 & 633 \\
\hline & 38.5 & 28.0 & 14.5 & 19.0 & 100 \\
\hline \multirow[t]{2}{*}{ Subang } & 265 & 163 & 90 & 62 & 580 \\
\hline & 45.7 & 28.1 & 15.5 & 10.7 & 100 \\
\hline \multirow[t]{2}{*}{ Purwakarta } & 443 & 216 & 116 & 103 & 878 \\
\hline & 50.5 & 24.6 & 13.2 & 11.7 & 100 \\
\hline \multirow[t]{2}{*}{ Karawang } & 442 & 184 & 127 & 113 & 866 \\
\hline & 51.0 & 21.2 & 14.7 & 13.0 & 100 \\
\hline \multirow[t]{2}{*}{ Bekasi } & 361 & 144 & 96 & 63 & 664 \\
\hline & 54.4 & 21.7 & 14.5 & 9.5 & 100 \\
\hline Bandung & 286 & 116 & 79 & 57 & 538 \\
\hline Barat & 53.2 & 21.6 & 14.7 & 10.6 & 100 \\
\hline \multirow[t]{2}{*}{ Pangandaran } & 233 & 130 & 83 & 88 & 534 \\
\hline & 43.6 & 24.3 & 15.5 & 16.5 & 100 \\
\hline Kota & & & & & \\
\hline Bogor & 686 & 273 & 160 & 141 & 1.260 \\
\hline & 54.4 & 21.7 & 12.7 & 11.2 & 100 \\
\hline Sukabumi & 306 & 148 & 102 & 93 & 649 \\
\hline & 47.1 & 22.8 & 15.7 & 14.3 & 100 \\
\hline Bandung & 606 & 264 & 131 & 143 & 1.144 \\
\hline & 53.0 & 23.1 & 11.5 & 12.5 & 100 \\
\hline Cirebon & 383 & 200 & 100 & 101 & 784 \\
\hline & 48.9 & 25.5 & 12.8 & 12.9 & 100 \\
\hline Bekasi & 364 & 140 & 69 & 80 & 653 \\
\hline & 55.7 & 21.4 & 10.6 & 12.3 & 100 \\
\hline Depok & 667 & 234 & 130 & 120 & 1.151 \\
\hline & 57.9 & 20.3 & 11.3 & 10.4 & 100 \\
\hline Cimahi & 555 & 276 & 133 & 129 & 1.093 \\
\hline & 50.8 & 25.3 & 12.2 & 11.8 & 100 \\
\hline Tasikmalaya & 381 & 159 & 106 & 96 & 742 \\
\hline & 51.3 & 21.4 & 14.3 & 12.9 & 100 \\
\hline Banjar & 292 & 131 & 92 & 95 & 610 \\
\hline & 47.9 & 21.5 & 15.1 & 15.6 & 100 \\
\hline
\end{tabular}

Tabel 7

Persentase Perundungan di 27 Kotal Kabupaten di Jawa Barat (dalam \%)

\begin{tabular}{lcccc}
\hline & $\begin{array}{c}\text { Tidak } \\
\text { pernah }\end{array}$ & Sekali & $\begin{array}{c}2-3 \\
\text { kali }\end{array}$ & $\begin{array}{c}>3 \\
\text { kali }\end{array}$ \\
\hline $\begin{array}{l}\text { Dipukul oleh saudara } \\
\text { kandung }\end{array}$ & 48.5 & 23.9 & 11.5 & 16.1 \\
$\begin{array}{l}\text { Dipanggil dengan nama } \\
\text { yang buruk oleh } \\
\text { saudara kandung }\end{array}$ & 61.1 & 20.5 & 8.2 & 10.2 \\
$\begin{array}{l}\text { Dipukul oleh anak lain } \\
\text { di sekolah }\end{array}$ & 47.5 & 25.4 & 14.4 & 12.7 \\
$\begin{array}{l}\text { Dipanggil dengan nama } \\
\text { yang buruk oleh anak }\end{array}$ & 39.4 & 23.9 & 15.8 & 20.9 \\
$\begin{array}{l}\text { lain di sekolah } \\
\begin{array}{l}\text { Dikucilkan oleh anak } \\
\text { lain di kelas }\end{array}\end{array}$ & 50.4 & 23.2 & 14.0 & 12.5 \\
\hline
\end{tabular}

Tabel 8

Persentase Perundungan Berdasarkan Jenis Kelamin dan Usia (dalam \%)

\begin{tabular}{lcccc}
\hline & $\begin{array}{c}\text { Tidak } \\
\text { pernah }\end{array}$ & Sekali & $\begin{array}{c}2-3 \\
\text { kali }\end{array}$ & $\begin{array}{c}>3 \\
\text { kali }\end{array}$ \\
\hline Dipukul oleh saudara kandung & & & \\
Laki-laki & 46.0 & 23.7 & 12.4 & 17.9 \\
Perempuan & 51.1 & 24.2 & 10.4 & 14.2 \\
8 Tahun & 55.5 & 20.1 & 10.9 & 13.4 \\
10 Tahun & 48.3 & 21.6 & 12.1 & 18.0 \\
12 Tahun & 43.1 & 29.3 & 11.2 & 16.4
\end{tabular}

Dipanggil dengan nama yang buruk oleh saudara kandung

$\begin{array}{llllc}\text { Laki-laki } & 60.5 & 19.6 & 8.5 & 11.4 \\ \text { Perempuan } & 62.5 & 21.3 & 7.4 & 8.7 \\ \text { 8 Tahun } & 59.0 & 22.3 & 9.7 & 9.0 \\ \text { 10 Tahun } & 65.0 & 17.0 & 8.3 & 9.7 \\ \text { 12 Tahun } & 60.7 & 21.9 & 6.2 & 11.2\end{array}$

Dipukul oleh anak lain di sekolah

$\begin{array}{lcccc}\text { Laki-laki } & 40.7 & 27.3 & 16.1 & 15.9 \\ \text { Perempuan } & 54.1 & 23.6 & 13.1 & 9.3 \\ \text { 8 Tahun } & 55.0 & 23.2 & 10.4 & 11.4 \\ \text { 10 Tahun } & 44.4 & 27.4 & 16.1 & 12.1 \\ \text { 12 Tahun } & 43.8 & 25.7 & 16.8 & 13.8\end{array}$

Dipanggil dengan nama yang buruk oleh anak lain di sekolah

$\begin{array}{lllll}\text { Laki-laki } & 37.6 & 23.3 & 116.4 & 22.6 \\ \text { Perempuan } & 41.0 & 24.4 & 14.8 & 19.9 \\ \text { 8 Tahun } & 48.3 & 25.4 & 14.6 & 11.7 \\ \text { 10 Tahun } & 37.0 & 24.0 & 16.2 & 22.9 \\ \text { 12 Tahun } & 33.7 & 22.4 & 16.0 & 27.8\end{array}$

Dikucilkan oleh anak lain di kelas

$\begin{array}{lllll}\text { Laki-laki } & 52.1 & 22.5 & 13.7 & 11.6 \\ \text { Perempuan } & 49.3 & 23.8 & 14.0 & 12.8 \\ \text { 8 Tahun } & 53.6 & 21.7 & 13.4 & 11.4 \\ \text { 10 Tahun } & 47.6 & 24.2 & 14.8 & 13.4 \\ \text { 12 Tahun } & 50.9 & 23.6 & 13.5 & 12.0\end{array}$


Tabel 8 memperlihatkan bahwa anak laki-laki lebih sering mengalami perundungan fisik dengan dipukul oleh saudara kandung lebih dari tiga kali (17.9\%) dan dipukul oleh anak lain di sekolah lebih dari tiga kali (15.9\%) dibandingkan anak perempuan pada kasus yang sama (masingmasing $14.2 \%$ dan 9.3\%). Untuk perundungan verbal, anak laki-laki juga lebih sering mengalami dipanggil dengan nama yang buruk, baik oleh saudara kandung (11.4\%) maupun oleh anak lain di sekolah (22.6\%). Sedangkan anak perempuan lebih sering mengalami perundungan dikucilkan oleh anak lain di kelas (12.8\%) dibandingkan anak laki-laki (11.6\%). Anak usia 12 tahun lebih sering mengalami perundungan verbal dipanggil dengan nama yang buruk, baik oleh saudara kandung (11.2\%) maupun oleh anak lain di sekolah (27.8\%) lebih dari 3 kali dalam satu bulan terakhir dibandingkan anak usia 8 dan 10 tahun. Anak usia 10 tahun lebih sering mengalami dikucilkan oleh anak lain di kelas dan dipukul oleh saudara kandung dibandingkan kelompok anak usia 8 dan 12 tahun.

\section{Pembahasan}

Perundungan merupakan permasalahan serius yang dihadapi anak-anak dan dapat memengaruhi proses tumbuh kembang mereka (Wolke dkk., 2000; Dombrowski \& Gischlar, 2006). Melalui penelusuran di Google Scholar dan mesin pencari lainnya, peneliti tidak menemukan penelitian di Indonesia yang memaparkan data mengenai frekuensi kejadian perundungan pada siswa sekolah dasar. Padahal sejumlah media massa menjelaskan tingginya angka kejadian perundungan di Indonesia, termasuk yang secara sengaja dipublikasikan oleh pelaku perundungan melalui media massa (Fikri, 2018). Beberapa penelitian terdahulu lebih mengeksplorasi mengenai dinamika psikologis yang terjadi pada korban perundungan dan bagaimana intervensi yang tepat sesuai dengan kasus perundungan yang terjadi (Ulfiah, 2008; Yuliati, 2013). Penelitian sebelumnya memang tidak banyak memaparkan data mengenai frekuensi atau jumlah secara detail kasus perundungan yang terjadi di beberapa wilayah di Indonesia. Sehingga kelebihan dari penelitian ini adalah menyajikan data yang lebih mutakhir dengan jumlah subjek yang mencakup populasi lebih besar.

Untuk mendapatkan gambaran mengenai dinamika psikologis yang terjadi ketika proses pengambilan data, maka peneliti menggunakan metode wawancara semi-terstruktur untuk mendapatkan gambaran yang terjadi pada siwa-siswi tersebut. Dalam proses pengambilan data di lapangan, anak-anak melaporkan bahwa mereka merasa bahagia mendapatkan kesempatan untuk mengisi kuesioner dalam penelitian ini. Mereka menyampaikan secara langsung kepada para enumerator setelah proses pengambilan data selesai dilaksanakan, bahwa mereka merasa berbahagia karena mendapatkan perhatian untuk didengar suaranya dan dapat melaporkan pengalaman tidak menyenangkan yang mereka alami sebagai korban perundungan. Selama ini, mereka merasa tidak memiliki wadah untuk dapat melaporkan kejadian tidak menyenangkan tersebut. Ada yang merasa tidak berani menyampaikan kepada orang dewasa (orang tua dan guru), ada juga yang merasa bahwa keluhan mereka mungkin tidak akan didengar dan ditanggapi. Berdasarkan pengalaman pengambilan data di lapangan tersebut, dapat dijelaskan bahwa anak-anak sesungguhnya mengalami perasaan tidak berdaya sebagai korban perundungan. Hal ini juga menjelaskan bahwa perundungan seringkali terjadi dalam keseharian mereka.

Melalui paparan deskripsi data perundungan ini, dapat dilihat bahwa angka kejadian perundungan pada anak-anak di 27 Kota/ Kabupaten di Jawa Barat tergolong tinggi. Pada semua perilaku perundungan, anak melaporkan bahwa mereka menjadi korban, baik di rumah maupun di sekolah. Semua kasus perundungan yang terjadi di wilayah Jawa Barat tersebut termasuk ke dalam kasus yang mengkhawatirkan, bahkan 
untuk beberapa daerah bisa mencapai berkali lipat angka kejadian terutama perundungan yang terjadi lebih dari tiga kali.

Data perundungan yang terjadi di 27 Kota/ Kabupaten di Jawa Barat selayaknya dicermati sebagai kondisi yang memprihatinkan. Tidak ada satupun Kota/ Kabupaten yang terlepas dari kasus perundungan, karena semua tipe perundungan (fisik, verbal, dan psikologis) terjadi di semua Kota/ Kabupaten. Hal ini menjelaskan bahwa perundungan seolah telah menjadi bagian dari kehidupan seharihari anak-anak. Hal ini seharusnya menjadi perhatian serius bagi orang tua, guru, dan institusi terkait dalam upaya membantu mencegah semakin meningkatnya kejadian perundungan pada anak-anak di Indonesia. Jumlah kasus perundungan ini mungkin akan terus meningkat setiap tahunnya mengingat belum ada intervensi atau kebijakan secara makro yang dilakukan oleh berbagai pihak untuk mengantisipasinya.

Secara umum, semua tipe perundungan terjadi cukup tinggi di semua Kota/ Kabupaten dengan angka kejadian lebih dari 3 kali mengalami menjadi korban perundungan. Artinya, anak-anak secara berulang menjadi korban perundungan. Kejadian perundungan yang terus terjadi melibatkan banyak pihak di dalamnya, tidak hanya mereka yang menjadi korban tetapi juga mereka yang menjadi pelaku perundungan tersebut. Kasus ini secara psikologis jika dibiarkan terus-menerus maka bukan tidak mungkin akan meningkat dengan drastis, disebabkan mereka yang menjadi korban mungkin bisa menjadi pelaku di kemudian hari karena mendapatkan tekanan secara psikologis yang mereka rasakan sebelumnya. Hal tersebut didukung oleh penelitian yang menyatakan bahwa kemungkinan mereka yang pernah menjadi korban akan melakukan hal yang sama dengan apa yang mereka rasakan jika situasinya terus tertekan dan mendesak (Gamayanti, 2009). Bahkan beberapa kasus perundungan yang menyakitkan tersebut mungkin akan menjadi termanifestasikan ke dalam pikiran negatif yang akan mengganggu kehidupan anak di kemudian hari dan terutama kesejahteraan mereka di lingkungannya (Khasanah, Damayanti, \& Sirodj, 2017).

Ketika rumah seharusnya menjadi tempat yang aman bagi anak-anak, namun data menunjukkan bahwa anak-anak lebih sering mengalami perundungan fisik di rumah daripada di sekolah (tabel 7) dengan dipukul oleh saudara kandungnya. Walaupun tidak ada keterangan mengenai posisi keurutan lahir anak dalam keluarga, namun tingginya kejadian perundungan fisik terjadi karena adanya ketidakseimbangan kekuatan dalam keluarga yang mengakibatkan anak mengalami pemukulan oleh saudara kandungnya sendiri. Eriksen dan Jensen (2009) menjelaskan bahwa perundungan fisik diantara saudara kandung merupakan bentuk kekerasan dalam keluarga yang paling umum terjadi. Aksesibilitas dan kebebasan yang tidak terbatas antara saudara juga menjadi salah satu faktor yang mungkin berkontribusi terhadap kasus perundungan di rumah.

Penelitian yang dilakukan oleh Tanrikulu dan Campbell (2015) menjelaskan adanya kaitan antara jenis kelamin dengan perundungaan yang dilakukan oleh saudara kandung. Pada penelitian ini, data menunjukkan bahwa anak laki-laki dan perempuan sama-sama mengalami perundungan fisik dan verbal oleh saudara kandung (tabel 8), dimana anak laki-laki lebih sering mengalami perundungan fisik $(17.9 \%)$ dan perundungan verbal $(11.4 \%)$ yang dilakukan oleh saudara kandung dibandingkan anak perempuan (masingmasing $14.2 \%$ dan $8.7 \%$ ). Anak perempuan juga lebih sering mengalami perundungan fisik $(14.2 \%)$ yang dilakukan oleh saudara kandung di rumah, daripada perundungan fisik $(9.3 \%)$ yang dilakukan anak lain di sekolah. Hal yang sama juga terjadi pada anak laki-laki, walaupun dalam persentase yang tidak terlalu jauh berbeda (masingmasing $17.9 \%$ dan $15.9 \%$ ).

Dunn (2002) menjelaskan bahwa dalam relasi dengan saudara kandung di rumah, 
anak perempuan pada umumnya lebih afektif dan jarang menampilkan konflik dibandingkan anak laki-laki. Hal ini menjelaskan keadaan bahwa anak perempuan menjadi lebih sering mengalami perundungan fisik oleh saudara kandung di rumah (14.2\%) dibandingkan di sekolah (8.7\%) karena adanya ketidakseimbangan kekuatan dengan saudara kandung yang berpotensi menyebabkan munculnya perundungan fisik yang dilakukan oleh saudara kandung. Banyak kasus perundungan yang terjadi di rumah tersebut seharusnya menjadi perhatian besar keluarga dalam memberikan kehangatan dan menciptakan kondisi keluarga yang nyaman.

Terkait perundungan di sekolah, anakanak melaporkan bahwa mereka sering dipanggil dengan nama yang buruk oleh anak lain di sekolah. Salah satu kondisi yang memprihatinkan, berdasarkan laporan dari anak-anak yang seringkali menjadi korban perundungan verbal ini, guru tidak selalu memahami bahwa anak-anak sedang menjadi korban perundungan verbal ketika diejek. Guru seringkali menilai bahwa memanggil anak lain dengan nama yang buruk dan mengejek, seolah sebagai suatu bentuk candaan. Padahal, bagi sebagian besar anak, hal ini dinilai sebagai perundungan verbal. Kasus perundungan yang dilakukan secara verbal memang menjadi sebuah kebiasaan yang seharusnya dihentikan oleh siapapun yang melakukannya. Kondisi seperti ini menjadi wadah koreksi bagi guru dan sekolah untuk menciptakan kesejahteraan siswa-siswi di sekolah tersebut.

Di sekolah, anak-anak juga seringkali mengalami perundungan fisik $(12.7 \%)$ dan psikologis (12.5\%) dengan angka kejadian yang relatif hampir sama. Data ini juga menunjukkan bahwa sekolah yang seharusnya menjadi tempat menyenangkan bagi anak-anak untuk menuntut ilmu, ternyata memiliki angka kejadian perundungan yang tinggi, baik perundungan fisik (pemukulan) maupun perundungan psikologis (pengucilan) oleh temantemannya. Dinamika psikologis dan perkembangan siswa di sekolah adalah hal yang sangat penting untuk dijadikan bahan evaluasi sekolah untuk meningkatkan kesejahteraan siswa di sekolah. Dengan adanya kasus perundungan dengan frekuensi tinggi tersebut, dibutuhkan usaha yang sangat keras untuk mengatasinya.

Tingginya angka kejadian perundungan dapat terjadi karena anak tidak memiliki kesempatan untuk menjelaskan pengalamannya. Jika anak diberikan kesempatan untuk mengekspresikan apa yang mereka rasakan selama di sekolah, akan menjadi salah satu langkah preventif yang efektif untuk menjaga stabilitas psikologis siswa. Melalui paparan data ini, maka diharapkan dapat menjadi perhatian serius bagi semua pihak, baik orang tua, guru, maupun para pengambil kebijakan, bahwa perundungan adalah persoalan yang harus segera diatasi.

Pada penelitian ini dapat dilihat bahwa anak-anak yang usianya lebih tua (12 tahun) lebih sering mengalami perundungan dibandingkan anak-anak yang usianya lebih muda (tabel 8), dengan pengecualian pada perundungan fisik oleh saudara kandung dan dikucilkan oleh anak lain di kelas, yang mana anak usia 10 tahun lebih sering mengalami kedua jenis perundungan tersebut. Perbedaan-perbedaan usia anak dalam melakukan perundungan juga banyak diperhatikan dalam penelitian ini supaya mampu mengakomodasi penelitian lainnya yang ingin mengeksplorasi lebih jauh perbedaan demografi anak dan perundungan.

Penelitian ini memiliki beberapa keterbatasan. Penelitian ini hanya berfokus pada deskripsi frekuensi tiap perundungan (fisik, verbal, dan psikologis) yang dilakukan oleh saudara kandung dan anak lain di sekolah pada anak usia 8, 10, dan 12 tahun di 27 Kota/ Kabupaten. Penelitian ini merupakan temuan awal dari survei internasional Children's Worlds di Indonesia, terutama terkait data frekuensi perundungan, sehingga data-data yang lebih komprehensif memang tidak disajikan dalam penelitian ini. Studi lain terkait perundungan, seperti kaitannya dengan kebahagiaan anak dan 
faktor-faktor penyebab terjadinya perundungan, dipaparkan dalam penelitian lanjutan pada artikel lain dari hasil survei internasional Children's Worlds di Indonesia.

\section{Simpulan}

Hasil penelitian ini menunjukkan bahwa angka kejadian perundungan di Jawa Barat tergolong tinggi dan memprihatinkan. Melalui paparan ini, diharapkan akan semakin tumbuh kesadaran pada orang tua dan guru mengenai seriusnya permasalahan perundungan ini. Ketika anak mengeluhkan bahwa dirinya menjadi korban perundungan, sebaiknya orang tua dan guru mendengarkan keluhan anak dan menanggapinya secara tepat. Bagi peneliti lain, paparan data perundungan ini kiranya dapat dijadikan data awal sebagai bahan rujukan untuk melakukan penelitian lanjutan, baik dengan mengacu pada data perundungan di tiap Kota/ Kabupaten, maupun perundungan terkait usia dan jenis kelamin.

\section{Daftar Pustaka}

Arseneault, L., Bowes, L., \& Shakoor, S. (2009). Bullying victimization in youths and mental healths problems: 'Much ado abouth nothing'?. Pscyhological Medicine, 40(5), 717-729.

Borualogo, I. S., Gumilang, E., Mubarak, A., Khasanah, A., Wardati, M. A., Diantina, F. P., Permataputri, I., \& Casas, F. (2018). Process of translation of the Children's Worlds Subjective Well-Being Scale in Indonesia. Social and Humaniora Research Symposium, 307, 180-183. Retrieved from https://www.atlantis-

press.com/proceedings/sores$18 / 55915312$

Casas, F. (2016). Children, adolescents and quality of life: The social sciences perspective over two decades. Dalam F. Maggino (eds). A life devoted to quality of life. Festschrift in honor of Alex c. Michalos. (pp. 3-21). Dordrecht: Springer Publisher.
Casas, F., Gonzalez, M., Navarro, D., \& Aligue, M. (2013). Children as advisers of their researchers: Assuming a different status for children. Child Indicator Research, 6, 193-212.

Chen, Ji-Kang., \& Wei, His-Sheng. (2011). The impact of school violence on selfesteem and depression among Taiwanese junior high school students. Social Indicators Research, 100(3), 479-498. doi.org/10.1007/s11205-0109625-4

Dombrowski, S. C., \& Gischlar, K. L. (2006). Supporting school professionals through the establishment of a school district policy on child maltreatment. Education, 127(2), 234-243.

Dunn, J. (2002). Sibling relationships. Dalam P. K. Smith, \& C. H. Hart (Eds.), Childhood social development, 223-237. Oxford: Blackwell.

Eriksen S., \& Jensen, V. A. (2009). A push or a punch: Distinguishing the severity of sibling violence. Journal of Interpersonal Violence, 24, 183-208.

Espelage, D. L., \& Swearer, S. M. (2003). Research on school bullying and victimization: What have we learned and where do we go from here? School Psychology Review, 32(3), 365-383.

Fikri, D. A. (2018). 4 kasus bullying paling menggemparkan di Indonesia, korbannya ada yang meninggal. Diakses dari

https://lifestyle.okezone.com/read/2018/ 05/04/196/1894566/4-kasus-bullyingpaling-menggemparkan-di-indonesiakorbannya-ada-yang-meninggal

Gamayanti, W. (2009). Tindak kekerasan yang dilakukan anak-anak sebagai upaya untuk memecahkan masalah yang diakibatkan tekanan lingkungan. Psympathic: Jurnal Ilmiah Psikologi, I(1), 1-14.

Gini, G., \& Pozzoli, T. (2013). Bullied children and psychosomatic problems: A meta-analysis. Journal of Pediatrics, 132(4), 720-729.

Kementerian Perencanaan Pembangunan Nasional (Bappenas) dan United 
Nations Children's Fund. (2017). Laporan Baseline SDG tentang AnakAnak di Indonesia Jakarta: BAPPENAS dan UNICEF.

Khasanah, A. N., Damayanti, T. \& Sirodj, D. A. N. (2017). Gambaran negative automatic thoughts pada remaja korban bullying di sekolah menengah pertama Kota Bandung. Psympathic: Jurnal Ilmiah Psikologi, 4(2). doi: 10.15575/psy.v4i2.1698.

Kim, Y. S., Koh, Y., \& Leventhal, B. (2005). School bullying and suicidal risk in Korean middle school students. Pediatrics, 115, 357-363.

Lenci, M., \& Matuga, J. (2010). The lifetime bully: Investigating the relationship between adolescent bullying and depression in early adulthood. Journal of School Counseling, 8(7), 1-31.

Martin K., Huebner E. S., \& Valois, R. F. (2008). Does life satisfaction predict victimization experiences in adolescence? Psychology in the Schools, 45, 705-714. doi.org/10.1002/pits.20336

Musu-Gillette, L., Zhang, A., Wang, K., Zhang, J., \& Oudekerk, B. A. (2017). Indicators of school crime and safety: 2016 (NCES 2017-064/NCJ 250650). National Center for Education Statistics, U.S. Department of Education, and Bureau of Justice Statistics, Office of Justice Programs, U.S. Department of Justice. Washington, DC. Diakses dari https://nces.ed.gov/pubs2017/2017064.pdf.

Novianto, R. D. (2018). Catatan KPAI bidang pendidikan: Kasus bullying paling banyak. Diakses dari https://nasional.sindonews.com/read/13 24346/15/catatan-kpai-bidangpendidikan-kasus-bullying-palingbanyak-1532346331

Olweous, D. (1997). Bully/victim problems in school: Facts and intervention. European Journal of Psychology of Education, 12(4), 495-510.

Pennington, K. (2018). David Beckham tackles bullying and violence in
Indonesian schools. Diakses dari https://www.reuters.com/article/usindonesia-education-celebrities/davidbeckham-tackles-bullying-andviolence-in-indonesian-schoolsidUSKBN1H4235

Perren, S., Ettekal, I., \& Ladd, G. (2013). The impact of peer victimization on later maladjustment: Mediating and moderating effects of hostile and selfblaming attributions. Journal of Child Psychology and Psychiatry, 54(1), 4655. Doi: https://dx.doi.org/10.1111\%2Fj.14697610.2012.02618.x

Savahl, S., Montserrat, C., Casas, F., Adams, S., Tiliouine, H., Benninger, E., \& Jackson, K. (2018). Children's experiences of bullying victimization and the influence on subjective wellbeing: A multinational comparison. Child Development, 00(00), 1-18.

Sindo Weekly (2017). Indonesia tempati posisi tertinggi perundungan di ASEAN. Diakses dari https://nasional.sindonews.com/read/12 23442/15/indonesia-tempati-posisitertinggi-perundungan-di-asean1500880739

Syed, N. (2018). How can school curb bullying. Diakses dari https://www.theeducatoronline.com/asia /news/how-can-schools-curbbullying/246896

Tanrikulu, I., \& Campbell, M. A. (2015). Sibling bullying perpetration: Associations with gender, grade, peer perpetration, trait anger, and moral disengagement. Journal of Interpersonal Violence, 30(6), 10101024.

Tiliouine, H. (2015). School bullying victimisation and subjective well-being in Algeria. Child Indicators Research, 8(1), 133-150.

Ulfiah, U. (2008). Penanganan perilaku bullying siswa melalui konseling model pengembangan komitmen beragama. Psympathic: Jurnal Ilmiah Psikologi, 
l(1), 67-74.

10.15575/psy.v1i1.2120.

U.S. Department of Education (2016). Student Reports of Bullying: Results from the 2015 school crime supplement to the National Crime Victimization Survey. Diakses dari https://nces.ed.gov/pubs2017/2017015. pdf.

Varela, J. J., Zimmerman, M. A., Ryan, A. M., Stoddard, S. A., Heinze, J. E., \& Alfaro, J. (2017). Life satisfaction school satisfaction, and school violence: A mediation analysis for Chilean adolescent victims and perpetrators. Child Indicators Research, 11(2), 487505. doi.org/10.1007/s12187-016-94427

Wang, J., Iannotti, R. J., \& Nansel, T. R. (2009). School bullying among adolescents in the United States: physical, verbal, relational, and cyber. Journal of Adolescent Health. 45, 368375.
Wolke, D., Woods, S., Bloomfield, L., \& Karstadt, L. (2000). The association between direct and relational bullying and behaviour problems among primary school children. Journal of Child Psychology, 41(8), 989-1002.

Yuliati, N. (2013). Mencegah tindak kekerasan dan tawuran antar pelajar melalui pengembangan program pelatihan social perspective taking di sekolah. Psympathic: Jurnal Ilmiah Psikologi, 6(1), 787-804. doi: 10.15575/psy.v6i1.2136. 
Psympathic, Jurnal Ilmiah Psikologi Juni 2019, Vol. 6, No. 1, Hal. : 15-30 